\title{
Effects of Two Different Feeding Strategies During Dry-Off on Metabolism in High-Yielding Dairy Cows
}

\author{
M. O. Odensten, ${ }^{1}$ Y. Chilliard, ${ }^{2}$ and K. Holtenius ${ }^{1}$ \\ ${ }^{1}$ Department of Animal Nutrition and Management, Swedish University of Agricultural Sciences \\ SE-753 23 Uppsala, Sweden \\ ${ }^{2}$ Unité Recherches sur les Herbivores, Centre INRA de Clermont-Ferrand-Theix, \\ 63122 Theix, France
}

\begin{abstract}
The objectives of this study were to investigate different feeding strategies of high-yielding dairy cows during dry-off. With a 12- to 13-mo calving interval and increasing milk yield, metabolic and health problems during the dry-off period will increase. Twenty-two dairy primiparous and multiparous cows were randomly assigned to 2 feeding treatments. One group was fed straw ad libitum (straw), and the other group was fed silage $(4 \mathrm{~kg} / \mathrm{d}$ of dry matter) daily and straw ad libitum (silage). At the dry-off point (d 0), the cows had an average milk yield of $17.1 \pm 0.8 \mathrm{~kg} / \mathrm{d}$. All cows were milked in the morning on $\mathrm{d} 3$ and 5 during the dry-off period. Rumen fluid was analyzed for volatile fatty acids (VFA), $\mathrm{pH}, \mathrm{NH}_{3}-\mathrm{N}$, and protozoa were counted from samples collected at $d-3,4$, and 17 . Total VFA concentration decreased at dry-off in both treatments and the drop was most pronounced among cows fed straw. Rumen $\mathrm{pH}$ increased significantly in both groups, and cows fed straw had significantly higher $\mathrm{pH}$ during dry-off. Ammonia $\mathrm{N}$ in rumen decreased significantly at dryoff and there was a tendency to lowered $\mathrm{NH}_{3}-\mathrm{N}$ in cows fed straw at dry-off. The plasma concentration of nonesterified fatty acids was markedly elevated during the dry-off period among cows in the straw treatment group, but was less pronounced among the cows fed silage with straw. The glucose level in plasma was not significantly affected during the dry-off period, and the insulin concentration was markedly reduced in both treatment groups. Plasma leptin concentration was lower in the lactating state than in the dry period. Both the $\beta$-hydroxybutyrate and urea concentrations in plasma were significantly reduced during dry-off. Our results indicate that dry-off markedly affected the metabolism in the blood and in the rumen of the cows, and

Received November 22, 2004.

Accepted March 1, 2005.

Corresponding author: Martin Odensten; e-mail: Martin.Odensten @huv.slu.se.
\end{abstract}

that the cows offered only straw during the dry-off were most affected.

(Key words: dry-off, metabolism, starvation, metabolic stress)

Abbreviation key: Ac = acetate, $\mathbf{B u}=$ butyrate, $\mathbf{E B}=$ energy balance, FIL = feedback inhibitor of lactation, HFI = cows selected for high milk fat percentage index, LFI = cows selected for low milk fat percentage index, $\mathbf{M E}=$ metabolizable energy, $\mathbf{P r}=$ propionate, $\mathbf{S L}=$ selection line.

\section{INTRODUCTION}

The dry-off period is probably, with the exception of the weeks around parturition, the most physiologically demanding period for the high-yielding dairy cow. Highyielding cows managed conventionally with a 12 - to 13mo calving interval are dried off when still producing significant quantities of milk. Yields of 25 to $30 \mathrm{~kg} / \mathrm{d}$ of milk at dry-off are not uncommon (Dingwell et al., 2001). At dry-off it is of vital importance that milk synthesis is rapidly inhibited to prevent milk leakage, which may negatively affect udder health (Dingwell et al., 2003). Dry-off induces reabsorption of milk and regression of mammary secretory epithelial cells (Stefano et al., 2002). In milk, a protein, feedback inhibitor of lactation (FIL), increases in late lactation and at dryoff. The FIL has a restraining effect on milk production, primarily by blocking constitutive secretion by the alveolar epithelial cells (Wilde et al., 1998). Concentrationdependence of autocrine inhibition in vivo suggests a mechanism in which the milk concentration of FIL increases as milk accumulates and is decreased by milk removal. The FIL has had a positive effect on apoptosis (programmed cell death) in mammary epithelial cells at the end of lactation and during involution (Stefano et al., 2002).

Reducing the nutrient supply also facilitates dry-off. This is a common practice among farmers; and feed advisors recommend a drastic reduction in nutrient supply during dry-off. Cows in early lactation that were deprived of food for $48 \mathrm{~h}$ responded with a marked 
reduction in milk production (Agenäs et al., 2003; Chelikani et al., 2004). Overnight starvation in rats reduces glucose uptake by the mammary glands by about $90 \%$ (Threadgold and Kuhn, 1984; Page and Kuhn, 1986). Metabolic stress in early lactation related to negative nutrient balance and its correlation to health disorders is well documented (Pryce et al., 1998). However, there is a lack of information about metabolic stress during the dry-off period, but concerns have been raised that major changes in the nutrient supply at dry-off might lead to metabolic disorders, especially among highyielding cows (Skidmore et al., 1997).

The objective of the following study was to determine the effects of 2 dry-off protocols with different nutrient supplies on rumen and intermediary metabolism, and on rate of milk production reduction.

\section{MATERIALS AND METHODS}

\section{Animals, Management, and Experimental Design}

Twenty-two primiparous and multiparous cows of the Swedish Red and White breed were included in this experiment. The study was carried out at the Swedish University of Agricultural Sciences in Uppsala, Sweden. The cows included in the study were bred with sires that were indexed for high (HFI) and low (LFI) milk fat percentage, but the selection lines (SL) had the same amount of energy produced in milk. The cows were selected based on their milk yield and udder health 1 wk before start of dry-off. The criteria were a yield of at least $15 \mathrm{~kg} / \mathrm{d}$ of milk and milk SCC below 100,000 cells $/ \mathrm{mL}$. The experiment was conducted during $6 \mathrm{mo}$ in the fall of 2002 . The cows were allocated into 6 groups according to expected time to parturition. In each group the cows were randomly assigned to 2 different dry-off diets.

The cows were held in individual tie stalls with straw and sawdust bedding throughout the experiment. Before dry-off the cows were fed according to their requirements based on the Swedish feeding recommendations (Spörndly, 2003). Individual feeding of silage and concentrate was performed at 0600, 0900, 1300, and 1700 $\mathrm{h}$ each day. The chemical composition and DM content of the feeds used are shown in Table 1. Water was available in automatic water bowls and the cows had free access to salt licks. The actual dry-off procedure lasted for $5 \mathrm{~d}$ and is referred to as dry-off (d 1 to 5 ). The first day of dry-off (d 1) occurred approximately 8 wk before parturition. The experiment started $1 \mathrm{wk}$ before $d 1$ and lasted $3 \mathrm{wk}$ after d 1, i.e., a total of 4 wk. The cows were randomly assigned to 2 different dry-off treatments. They were fed 2 different diets during these $5 \mathrm{~d}$. During the dry-off one treatment group
Table 1. Dry matter content, chemical composition, and calculated values for metabolizable energy (ME), crude fat, $\mathrm{CP}, \mathrm{NDF}, \mathrm{ADF}$, and lignin.

\begin{tabular}{lrrc}
\hline & Silage & Straw & Concentrate \\
\hline $\mathrm{DM}, \%$ & 34.1 & 90.9 & 89.94 \\
$\mathrm{ME}, \mathrm{MJ} / \mathrm{kg}$ of DM & 10.9 & 7.0 & 14.02 \\
$\mathrm{AAT},{ }^{1}$ g/kg of DM & 71.3 & 47.1 & 119.35 \\
$\mathrm{PBV}$, g/kg of DM & 20.0 & -54.6 & 22.67 \\
$\mathrm{CP}, \mathrm{g} / \mathrm{kg}$ of DM & 140.9 & 41.0 & 213.7 \\
$\mathrm{Crude}$ fat, g/kg of DM & $\ldots$ & $\ldots$ & 69.3 \\
$\mathrm{NDF}, \mathrm{g} / \mathrm{kg}$ of DM & 491.1 & 773.9 & $\ldots$ \\
$\mathrm{ADF}, \mathrm{g} / \mathrm{kg}$ of DM & 302.2 & 512.8 & $\ldots$ \\
Lignin, g/kg of DM & 50.9 & 105.3 & $\ldots$ \\
Ash, \% of DM & 84.2 & 89.4 & $\ldots$ \\
$\mathrm{pH}$ & 4.0 & $\ldots$ & $\ldots$ \\
$\mathrm{NH}$ & & $\ldots$ & $\ldots$ \\
\hline
\end{tabular}

${ }^{1} \mathrm{AAT}=$ Amino acids absorbed in the small intestine (Spörndly, 2003).

${ }^{2} \mathrm{PBV}=$ Protein balance in the rumen (Spörndly, 2003).

(straw, $\mathrm{n}=11$ ) was fed straw ad libitum and the other treatment group (silage, $\mathrm{n}=11$ ) was fed $4 \mathrm{~kg} / \mathrm{d}$ of DM silage and straw ad libitum. Due to an abortion, 1 cow was excluded from the experiment in the silage group. All cows were fed minerals according to their requirements. From d 6 to 12, all cows were adapted to a dry period feed ration consisting of $6 \mathrm{~kg} / \mathrm{d}$ of DM silage and $1 \mathrm{~kg} / \mathrm{d}$ of DM concentrate.

The cows were milked twice a day the week before dry-off, at 0500 and $1600 \mathrm{~h}$. Milk yield was registered daily during the week before dry-off ( $\mathrm{d}-5$ to 0 ) and samples for milk composition analysis were obtained on 4 occasions (p.m. milking on $\mathrm{d}-6$ and -3 ; and a.m. milking on $d-5$ and -2 ). During the dry-off period, cows were milked at 2 occasions, in the mornings of $d 3$ and 5. Samples for milk composition analysis were also collected during these 2 milkings. The Uppsala Local Ethics Committee approved the experimental design.

\section{Samplings and Analyses}

Feed. Silage and concentrate feed samples were collected once weekly. Weekly samples were pooled before analysis. Straw feed samples were collected every day whenever straw was included in the diet. The individual feed components were dried at $60^{\circ} \mathrm{C}$ in a forced-air oven for $24 \mathrm{~h}$ and ground in a hammer mill (1-mm screen). The DM content was obtained by drying the ground feed at $105^{\circ} \mathrm{C}$ overnight. The dried feed components were ashed at $550^{\circ} \mathrm{C}$ for $5 \mathrm{~h}$ to determine the organic matter in the feed. Silage and straw samples were analyzed for NDF, ADF, and lignin according to Goering and Van Soest (1970). Feeds were analyzed for CP by a fully automated Kjeldahl procedure (Technicon, Solna, Sweden). Metabolizable energy (ME) in the feeds was 
calculated from in vitro digestibility (Lindgren, 1979). Amino acids absorbed in the small intestine and protein balance in the rumen were calculated according to the Nordic Protein Evaluation System as modified in the Swedish Feed Tables for Ruminants (Spörndly, 2003).

Blood. Blood samples were collected from the jugular or coccygeal vessel into evacuated Vacutainer tubes containing sodium heparin as anticoagulant (Venoject, Terumo Europe N.V. 3001, Leuven, Belgium). The blood sampling was performed between 1000 and $1100 \mathrm{~h}$ each day. The samples were kept on ice until centrifuged (8 min at $1800 \times g$ ) within $1 \mathrm{~h}$ after sampling, and the plasma was stored at $-20^{\circ} \mathrm{C}$ until analyzed.

Blood was collected on d $-5,-4,-2,1,2,3,4,5,6,7$, $8,10,12,15$, and 19 in relation to the dry-off day, $\mathrm{d} 1$. The plasma was analyzed for insulin, glucose, NEFA, BHBA, and urea at all time points. The insulin concentration in blood was analyzed with a commercial radioimmunoassay method evaluated for bovine (Coat-ACount, Diagnostics Products Corp., Los Angeles, CA). Enzymatic determinations were used for glucose (Peridochrom Glucose, Boehringer Mannheim Diagnostica, Mannheim, Germany), NEFA (NEFA C, Wako, Richmond, VA), BHBA (Sigma, St. Louis, MO), and urea (Unimate 5 urea, Hoffman-LaRoche, Basel, Switzerland). The leptin concentration in blood plasma was analyzed in samples collected on $\mathrm{d}-2,2,5,7,12$, and 19 , with an ovine-specific radioimmunoassay method validated and evaluated for bovine leptin (Delavaud et al., 2002).

Rumen. Rumen fluid was collected into prewarmed thermos bottles using an esophageal tube. Samplings were performed $2 \mathrm{~h}$ before the $1300 \mathrm{~h}$ feeding. Three samples per cow were collected 1 wk before dry-off (d -4 ), during dry-off (d 3), and 2 wk after dry-off (d 17). The $\mathrm{pH}$ was measured with a $\mathrm{pH}$ meter (MP125, Mettler-Toledo, GH-8603, Schwerzenbach, Switzerland) within 2 min of collection. A subsample of rumen fluid was directly frozen at $-20^{\circ} \mathrm{C}$. One milliliter of rumen fluid was transferred to a tube containing $9 \mathrm{~mL}$ of a preservative suspension containing $\mathrm{H}_{2} \mathrm{O}$, glycerol, and formaldehyde for protozoa counting.

The rumen fluid samples were analyzed for VFA and ammonium nitrogen $\left(\mathrm{NH}_{3}-\mathrm{N}\right)$. Volatile fatty acids were determined by the HPLC method as described by Andersson and Hedlund (1983), and $\mathrm{NH}_{3}-\mathrm{N}$ was determined on a Technicon AutoAnalyzer (Broderick and Kang, 1980). Total VFA were defined as the sum of propionate $(\mathbf{P r})$, butyrate $(\mathbf{B u})$, acetate $(\mathbf{A c})$, and valerate. Calculated values of the proportions of $\mathrm{Pr}, \mathrm{Bu}$, and Ac as a molar percentage of VFA were determined. The number of protozoa $\times 10^{5}$ per milliliter was counted on a microscope at a magnification of $100 \times$ in a $0.2-\mathrm{mL}$ counting chamber after serial dilution. From each sam- ple, duplicate measurements were used and the average was used to determine the number of protozoa present in the initial sample.

\section{Statistical Analyses}

Statistical ANOVA was performed on all data using PROC MIXED (SAS Institute, 2001). Least square means were compared with comparison-wise error rate after significant $F$-test. Least significant difference values were based on calculations with $t_{0.975}$. Values for late lactation were calculated as means of 3 samples before dry-off were used in the ANOVA for blood parameters, whereas individual values were used in the ANOVA for rumen parameters. The analysis of the blood parameter values was performed on mean values of 3 samples before dry-off and after dry-off on individual samples. The time factor (day) was divided into 2 classes, defining data as before or after dry-off. The model used different variances among subjects for the 2 period classes and different autoregressive covariance structure for the within-subject variations. Nonesterified fatty acids and insulin values were not normally distributed and the statistical analysis was performed on the logarithm values. Effect of milk yield at dry-off was tested in the initial model, but the effect was not significant $(P>0.05)$ and therefore was disregarded.

The effect of date to expected parturition and parity was found to be nonsignificant when tested in the procedure mixed model and was therefore not included in the milk composition model. Values shown in the text are presented as least square means \pm SEM, unless otherwise stated.

PROC MIXED Model:

\section{Classes ID PER T G DAY SL PAR}

model $(\mathrm{y})=\mathrm{T}$ G DAY SL PAR $\mathrm{T} \times$ Day

where ID = cow ID; PER = before and after dry-off; $\mathrm{T}=$ treatment (Straw or Silage); $\mathrm{G}=$ date of expected parturition (Group 1 to 6); DAY = sample date (in relation to dry-off referred as d 0); SL = selection line (HFI or LFI); PAR = parity (primiparous or multiparous cows); and $\mathrm{T} \times$ Day $=$ interaction between $\mathrm{T}$ and Day.

\section{RESULTS}

\section{Feed, Milk Yield, and Milk Composition}

Day 1 was $67 \pm 15 \mathrm{~d}$ before parturition. There were 12 primiparous cows and 9 multiparous cows in this experiment. Of the 12 primiparous cows, 5 were in the straw treatment and 7 were in the silage treatment. 
Table 2. Least square means and $F$-tests of fixed effects included in the model for fat, protein, and lactose in milk. Fixed effects are treatment (T), selection line (SL), and sample day (Day), and the interaction between $\mathrm{T} \times$ Day.

\begin{tabular}{|c|c|c|c|c|c|c|c|}
\hline & \multirow[b]{2}{*}{ Day } & \multicolumn{2}{|c|}{ Treatment $(\mathrm{LSM} \pm \mathrm{SE})$} & \multicolumn{4}{|c|}{ Fixed effects $P$ value } \\
\hline & & Straw & Silage & $\mathrm{T}$ & SL & Day & $\mathrm{T} \times$ Day \\
\hline \multirow[t]{3}{*}{ Milk fat, $\%$} & -3 & $4.72 \pm 0.19$ & $5.08 \pm 0.21$ & \multirow[t]{3}{*}{0.52} & \multirow[t]{3}{*}{0.03} & \multirow[t]{3}{*}{$<0.0001$} & \multirow[t]{3}{*}{0.26} \\
\hline & 3 & $6.23 \pm 1.03$ & $6.22 \pm 1.08$ & & & & \\
\hline & 5 & $13.27 \pm 1.03$ & $11.24 \pm 1.08$ & & & & \\
\hline \multirow{3}{*}{ Milk protein, $\%$} & -3 & $3.75 \pm 0.08$ & $4.04 \pm 0.08$ & \multirow[t]{3}{*}{0.63} & \multirow[t]{3}{*}{0.13} & \multirow[t]{3}{*}{$<0.0001$} & \multirow{3}{*}{0.85} \\
\hline & 3 & $5.48 \pm 0.32$ & $5.57 \pm 0.34$ & & & & \\
\hline & 5 & $6.63 \pm 0.32$ & $6.65 \pm 0.34$ & & & & \\
\hline \multirow{3}{*}{ Milk lactose, $\%$} & -3 & $4.70 \pm 0.05$ & $4.71 \pm 0.05$ & \multirow[t]{3}{*}{0.09} & \multirow[t]{3}{*}{0.37} & \multirow[t]{3}{*}{$<0.0001$} & \multirow[t]{3}{*}{0.10} \\
\hline & 3 & $3.48 \pm 0.18$ & $3.63 \pm 0.19$ & & & & \\
\hline & 5 & $2.53 \pm 0.18$ & $3.12 \pm 0.19$ & & & & \\
\hline
\end{tabular}

Of the 9 multiparous cows, 6 were in the straw treatment and 3 were in the silage treatment. The chemical composition of silage, straw, and concentrate is shown in Table 1. Before dry-off the cows fed straw were fed $10.8 \pm 0.3 \mathrm{~kg} / \mathrm{d}$ of silage DM and $5.6 \pm 0.1 \mathrm{~kg} / \mathrm{d}$ of concentrate $\mathrm{DM}$, and the cows fed silage with straw were fed $10.7 \pm 0.3 \mathrm{~kg} / \mathrm{d}$ of silage DM and $6.0 \pm 0.3 \mathrm{~kg} / \mathrm{d}$ of concentrate DM. All cows fed silage during the dry-off period consumed their silage ration $(4 \mathrm{~kg} / \mathrm{d}$ of DM). The cows receiving straw consumed $5.6 \pm 0.7 \mathrm{~kg} / \mathrm{d}$ of DM as straw, and the cows fed silage and straw consumed 4.8 $\pm 0.3 \mathrm{~kg} / \mathrm{d}$ of DM as straw. Due to technical problems, the straw consumption data were based on 12 cows, equally distributed between the 2 treatments.

The milk yield before dry-off was $16.8 \pm 0.8 \mathrm{~kg} / \mathrm{d}$ for the cows fed straw and $17.3 \pm 0.8 \mathrm{~kg} / \mathrm{d}$ in the cows fed silage with straw. All cows reduced their milk production during dry-off and there was no difference in milk production between dry-off treatments. The cows fed straw and the cows fed silage with straw had milk yields of $9.0 \pm 0.6$ and $9.2 \pm 0.6 \mathrm{~kg} / \mathrm{d}$ at $\mathrm{d} 3$ and $2.3 \pm 0.3$ and $4.2 \pm 0.6 \mathrm{~kg} / \mathrm{d}$ at d 5 , respectively. The primiparous cows had an average milk yield of $17.3 \pm 0.8 \mathrm{~kg} / \mathrm{d}$ and the multiparous cows had an average milk yield of $16.7 \pm$ $1.0 \mathrm{~kg} / \mathrm{d}$. The primiparous and multiparous cows had milk yields of $8.3 \pm 0.5$ and $10.3 \pm 3.6 \mathrm{~kg} / \mathrm{d}$ at $\mathrm{d} 3$ and $3.6 \pm 0.5$ and $2.8 \pm 0.6 \mathrm{~kg} / \mathrm{d}$ at d 5, respectively. Milk composition is shown in Table 2 . The milk fat percentage increased in both treatment groups, but the increase was most pronounced among the cows fed straw. There was a significant effect of SL where the cows bred for high milk fat had higher milk fat percentage. Milk protein increased in both treatment groups during the dry-off procedure, and at d 5 of dry-off, the concentration was almost doubled, whereas the milk lactose percentage decreased in both treatments.

\section{Plasma Metabolites and Hormones}

The plasma concentrations of insulin, glucose, NEFA, BHBA, and urea are presented in Figures 1 and 2 . Table 3 shows $P$ values from the $F$-tests of fixed effects included in the model for plasma concentrations of NEFA, glucose, BHBA, urea, insulin, and leptin.

A decrease in plasma insulin was observed in both treatment groups during dry-off compared with late lactation. The decrease was most pronounced in cows in the straw treatment, and these cows had lower levels during the entire dry-off period. At d 10, i.e., $5 \mathrm{~d}$ after the introduction of the dry-period feed ration, the insulin level had returned to the level observed before dryoff. The plasma glucose concentration did not differ significantly from the control value during dry-off, other than a transient increase during $\mathrm{d} 2$ and 3 in cows fed silage. The silage treatment group had a significantly higher glucose concentration in plasma from d 2 to 6 compared with cows that received only straw during dry-off. A significant effect of SL was also seen. Overall, HFI cows had a lower glucose level $(3.60 \pm 0.03 \mathrm{mM})$ than LFI cows $(3.76 \pm 0.04 \mathrm{mM})$. Plasma NEFA increased after dry-off in both treatment groups, but the increase was more pronounced in the straw treatment. The concentration had returned to the level before dryoff $3 \mathrm{~d}$ after the end of dry-off (d 10). Parity had a significant effect on plasma NEFA, with significantly higher NEFA values in primiparous cows than in multiparous cows. The BHBA concentration decreased in both treatment groups during dry-off and remained lower than in late lactation throughout the study. The decrease in BHBA was most pronounced in cows in the silage treatment, but there was no significant treatment effect. A decrease in plasma urea concentrations was observed on d 2 during dry-off. The decrease was most pronounced in the straw treatment. Primiparous cows had an overall lower urea plasma concentration 


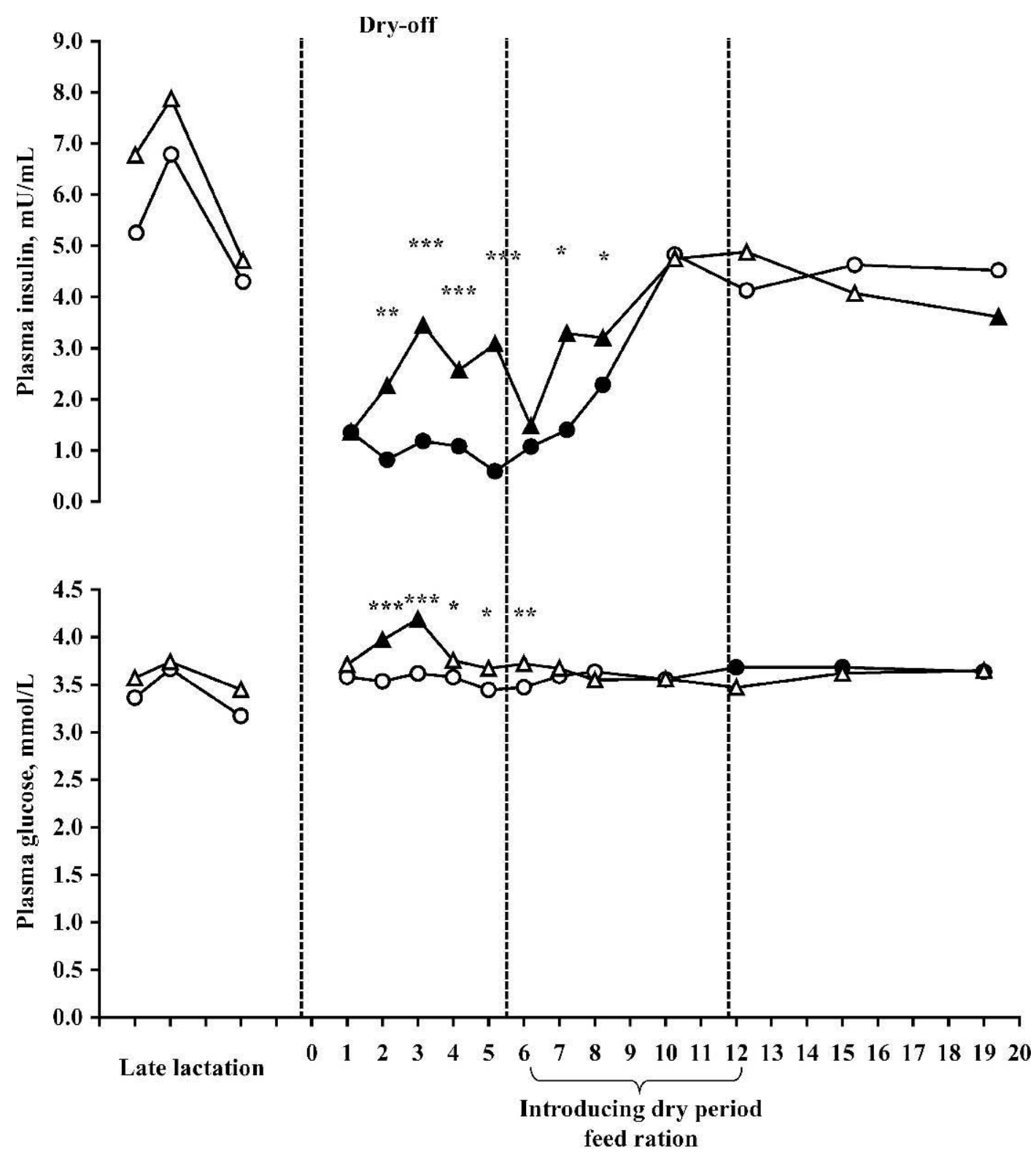

Days

Figure 1. Mean concentrations of insulin and glucose in plasma around dry-off. The symbols represent cows from the 2 treatment groups, straw $(\bigcirc)$ and silage $(\triangle)$. Values that differ significantly $(P<0.05)$ from the values before dry-off (mean from 3 samples) within treatment are indicated with filled symbols $(\bullet, \mathbf{\Delta})$. Values that differ between treatments within the same day are marked: $* P<0.05, * * P<0.01$, and $* * * P<0.0001$.

$(3.51 \pm 0.12 \mathrm{mM})$ than multiparous cows $(3.98 \pm 0.14$ $\mathrm{m} M)$. There was no difference in plasma leptin concentrations between the 2 treatments and therefore these data were merged. At d 2 of dry-off, the plasma leptin concentration was $5.14 \pm 0.24 \mathrm{ng} / \mathrm{mL}$ and did not differ from the levels before dry-off ( $5.14 \pm 0.23 \mathrm{ng} / \mathrm{mL})$, but significantly lower values were observed at d 5 and 7 , $4.41 \pm 0.24$ and $4.55 \pm 0.24 \mathrm{ng} / \mathrm{mL}$, respectively. After the cows had been introduced to the dry-period feed ration, the leptin concentration returned to the level before dry-off at d 12, but was significantly higher on d $19(6.57 \pm 0.24 \mathrm{ng} / \mathrm{mL})$. There was an effect on parity in which primiparous cows had lower $(4.95 \pm 0.16 \mathrm{ng} /$ $\mathrm{mL}$ ) plasma leptin than did multiparous cows (5.57 \pm $0.18 \mathrm{ng} / \mathrm{mL}$ ). There was a significant effect of group on all the measured plasma parameters except urea. 



Days

Figure 2. Mean concentrations of NEFA, BHBA, and urea in plasma around dry-off. The symbols represent cows from the 2 treatment groups, straw $(\bigcirc)$ and silage $(\triangle)$. Values that differ significantly $(P<0.05)$ from the values before dry-off (mean from 3 samples) within treatment are indicated with filled symbols $(\mathbf{O}, \mathbf{\Delta})$. Values that differ between treatments within the same day are marked: $* P<0.05, * * P$ $<0.01$, and $* * * P<0.0001$. 
Table 3. Probability values from the $F$-tests of fixed effects included in the model for plasma concentrations of NEFA, glucose, BHBA, urea, insulin, and leptin. Fixed effects are treatment (T), group (G), sample day (Day), selection line (SL), parity (PAR), and the interaction between $\mathrm{T} \times$ Day.

\begin{tabular}{lllllll}
\hline & \multicolumn{7}{c}{ Fixed effects, $P$ values } \\
\cline { 2 - 7 } & $\mathrm{T}$ & $\mathrm{G}$ & Day & $\mathrm{SL}$ & $\mathrm{PAR}$ & $\mathrm{T} \times$ Day \\
\hline NEFA $^{1}$ & 0.001 & 0.02 & 0.001 & 0.87 & 0.02 & 0.001 \\
Glucose & 0.002 & 0.003 & 0.001 & 0.02 & 0.68 & 0.002 \\
BHBA & 0.07 & 0.001 & 0.001 & 0.33 & 0.11 & 0.21 \\
Urea & 0.45 & 0.32 & 0.001 & 0.35 & 0.06 & 0.04 \\
Insulin $^{1}$ & 0.001 & 0.003 & 0.001 & 0.71 & 0.90 & 0.001 \\
Leptin & & 0.004 & 0.001 & 0.24 & 0.03 & \\
\hline
\end{tabular}

${ }^{1}$ Logarithmic values.

\section{Rumen Fluid}

Least square means and $F$-tests of fixed effects included in the model for total VFA, molar percentage of total VFA for $\mathrm{Pr}, \mathrm{Ac}$, and $\mathrm{Bu}, \mathrm{pH}, \mathrm{NH}_{3}-\mathrm{N}$, and protozoa are shown in Table 4. The rumen concentration of total VFA, as well as the individual acids ( $\mathrm{Pr}, \mathrm{Ac}$, and $\mathrm{Bu}$ ) decreased during dry-off. With the exception of $\mathrm{Bu}$, the concentrations decreased 2-fold during dry-off in the straw treatment compared with the silage treatment. Two weeks after dry-off there was no difference between treatment groups. The concentrations of total VFA, Pr, and Ac were significantly higher in LFI cows than in HFI cows, and concentrations were significantly lower in primiparous than in multiparous cows. In the straw treatment, the molar proportion of $\mathrm{Pr}$ and Bu decreased during dry-off, whereas the molar proportion of Ac increased. Two weeks after dry-off in the straw treatment, the proportions of the individual VFA were similar to those before dry-off. During the same period, the molar percentage of $\mathrm{Bu}$ declined and returned to the same level as before dry-off. There was a strong interaction between day and treatment in $\mathrm{Ac}, \mathrm{Pr}$, and $\mathrm{Bu}$ molar percentages of VFA. There was a significant effect of day on rumen $\mathrm{pH}$. The $\mathrm{pH}$ was higher at the sampling performed during dry-off than during the other 2 samplings. The rumen fluid $\mathrm{pH}$ was higher among the cows

Table 4. Least square means and $F$-tests of fixed effects included in the model for total VFA, propionate, acetate, and butyrate molar percentage of VFA, $\mathrm{pH}, \mathrm{NH}_{3}-\mathrm{N}$, and protozoa. Fixed effects are treatment (T), selection line (SL), parity (PAR), sample day (Day) and the interaction between $\mathrm{T} \times$ Day.

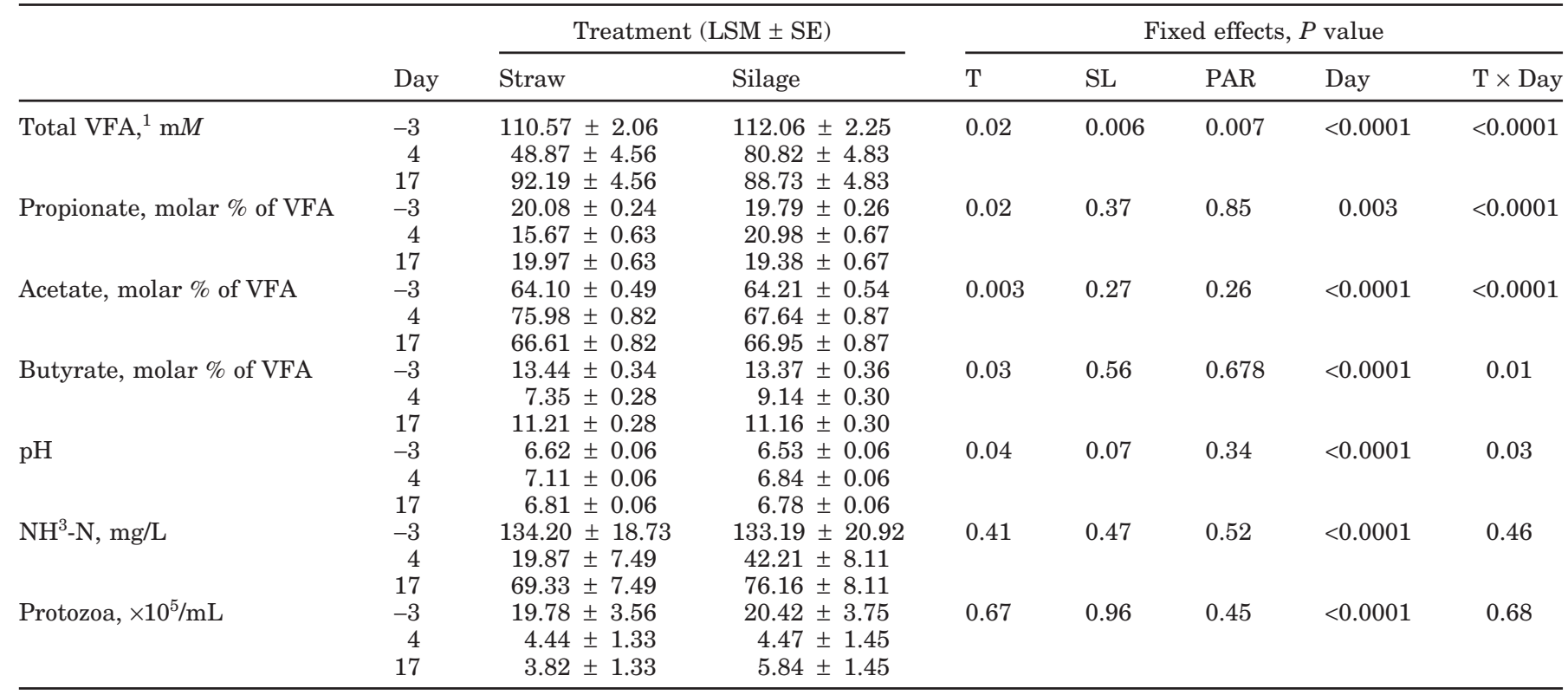

\footnotetext{
${ }^{1} \mathrm{VFA}=$ Propionate + acetate + butyrate + valerate .
} 
fed straw compared with the cows receiving straw and silage in the samples taken during dry-off. Ammonia $\mathrm{N}$, and protozoa count decreased during dry-off in both treatment groups but did not differ between treatments.

\section{DISCUSSION}

A rapid inhibition of milk production at dry-off is vital to minimize mammary infections after parturition (Dingwell et al., 2001). Different strategies, including reduction of available feed nutrients and less frequent milking, are often used to reduce milk production (Skidmore et al., 1997). In the present study, the effects of 2 dry-off strategies differing in feed allowances during dry-off were investigated. Both strategies resulted in rapid inhibition of milk production. During dry-off, the ME consumption of the straw and silage treatments dropped to 23 and $45 \%$, respectively, of the level before dry-off calculated from Spörndly (2003). Dairy cows subjected to feed deprivation in early lactation respond with a significant reduction in plasma glucose with a concomitant marked decrease in milk yield (Agenäs et al., 2003; Chelikani et al., 2004). Lactose synthesis, and therefore, overall milk yield, is positively correlated with glucose uptake by the mammary gland in ruminants (Nielsen and Jacobsen, 1993). The dry-off procedures appear to reduce mammary uptake of glucose from the blood for lactose. According to Baumrucker (1985), mammary uptake is determined by supply to the gland and transmembrane transport into the cells, where supply is a function of arterial nutrient concentration and mammary blood flow. In the present study, arterial concentration of glucose was not measured, but the difference in concentration between arterial blood plasma, and jugular and coccygeal plasma, is negligible. It is thus reasonable to assume that the plasma glucose levels observed in the present study reflected arterial levels (Nielsen et al., 2001). It is interesting that although the nutrient intake was markedly reduced during dry-off, the cows were able to maintain the plasma level of glucose at a level similar to or higher than before dry-off. Inhibition of milk synthesis was thus not induced by reduced blood concentration of glucose. The lactose concentration was markedly reduced in milk sampled during dry-off. A similar reduction in milk lactose was observed in feed-deprived cows in early lactation reflecting a reduced mammary glucose uptake (Agenäs et al., 2003; Chelikani et al., 2004). It is likely that decreased mammary glucose uptake in the present study was caused by down-regulation of glucose transport protein (Shennan and Peaker, 2000). However, decreased blood flow and prolonged transit time of blood through the mammary gland might also have contributed (Davis and Collier, 1985; Farr et al., 2000).

Increased plasma BHBA has frequently been used as a marker for identifying animals in a negative energy balance (EB; Duffield, 2000). In the present study, BHBA in plasma was reduced by both treatments during dry-off in spite of the negative EB. It has been shown previously that cows subjected to feed deprivation in wk 10 of lactation did not respond with increased BHBA in plasma (Agenäs et al., 2003), and that in dry (nonpregnant) cows, plasma BHBA was decreased by underfeeding (Chilliard et al., 1995). The BHBA in peripheral blood could emanate from incomplete oxidation of NEFA by the liver, or from Bu of rumen origin partly oxidized in the rumen epithelium to BHBA (Kristensen et al., 2000). The rumen concentration of Bu was markedly reduced at dry-off. It is therefore reasonable to assume that epithelial production of BHBA was reduced, and thus, contributed to the reduction in plasma BHBA. Chilliard et al. (1995) and Drackley (1999) concluded that BHBA is only suitable as a marker of EB in early lactation, similar to results of this study. There were generally small differences in the basal level of insulin and metabolites in plasma of cows selected for different fat content in milk, which agrees with previous reports (Murphy et al., 2000; Agenäs et al., 2003). In the present study, however, cows selected for low fat content in milk had a higher plasma glucose level than the cows selected for high fat content. The reason for this is not clear and has not been observed previously.

There is convincing evidence that insulin stimulates leptin synthesis and secretion in vivo and in vitro in ruminant adipose tissue (Chilliard et al., 2001). Fasting has induced a marked reduction in leptin, both in early lactating cows and in postpubertal heifers concomitant with a decrease in insulin (Chelikani et al., 2004), as did underfeeding in dry, nonpregnant cows (Delavaud et al., 2002). In the present study, leptin was not affected by dry-off at $2 \mathrm{~d}$ after introduction of the dry-off protocol, in spite of a significant decrease in plasma insulin. On the fifth day, a modest reduction $(-19 \%)$ in leptin was observed. There was no difference in leptin between the 2 dry-off treatments despite a pronounced difference between the treatment groups in dry-off energy intake. The plasma level of insulin was lower and NEFA was higher in the cows fed straw indicating a deeper negative EB. Thin, underfed cows with a negative EB had higher plasma leptin during the dry period than in the lactating state even though they were in positive EB and had gained BCS in previous reports (Agenäs et al., 2003; Holtenius et al., 2003). It was therefore suggested that lactation is a negative regulator of leptin (Holtenius et al., 2003), and this was recently confirmed in goats because lactation inhibited 
the leptin increase during early-pregnancy, and dryingoff late-lactating, nonpregnant goats in positive energy balance strongly increased plasma leptin (Bonnet et al., 2005). In agreement with those results, in the present study plasma leptin was lower in late lactation than in the early dry period. The cows were fed individually according to their requirements both during late lactation and in the early dry period. It is therefore assumed that the differences in BCS and EB have mostly been small, and thus would not explain the difference in leptin. Primiparous cows had higher NEFA concentration and lower leptin concentration in plasma than multiparous cows. It is possible that the primiparous cow had a more unbalanced metabolic/endocrine profile than that of multiparous cows, as suggested by Meikle et al. (2004). These authors further proposed that primiparous cows recover from a negative EB period with more difficulty.

Within $18 \mathrm{~h}$ after cessation of milking there are lasting changes in the mammary tissue that affect milk production; after about $36 \mathrm{~h}$, milk secretion is completely inhibited (Hamann and Dodd, 1992; Stelwagen and Lacy-Hulbert, 1996). It has been suggested that the protein FIL induces apoptosis in mammary epithelial cells at the end of lactation (Stefano et al., 2002). Capuco et al. (1997) suggested that accumulated FIL and increased alveolar pressure cause the decline in milk secretion at dry-off. In the present study, the milk protein concentration increased during dry-off, indicating that mammary protein synthesis was maintained. In mice, FIL inhibited milk protein synthesis in the mammary epithelial cell (Rennison et al., 1993). This finding suggests that other factors might have contributed to inhibited milk production in the present study. The concentration of fat in milk from the 2 milkings performed during dry-off was markedly increased compared with the concentration before dry-off. A similar response occurred in feed-deprived dairy cows (Agenäs et al., 2003; Chelikani et al., 2004) and in other species during feed restriction (Vernon and Pond, 1997). It has been suggested that this mechanism supplies energy to the young at the expense of maternal tissue mobilization when available dietary energy is scarce (Vernon and Pond, 1997).

Ruminal ammonia concentration was markedly reduced on the third day of the dry-off period, compared with that before dry-off in both treatments. A concomitant decrease in plasma urea concentration reflected the reduced ammonia concentration. The ruminal ammonia concentration was numerically lower and the drop in plasma urea concentration was deeper in the straw-fed cows. Underfeeding strongly decreased plasma urea and Ac in dry, nonpregnant sheep (Bocquier et al., 1998); and Marini and Van Amburgh (2003) showed a strong relationship between dietary $\mathrm{N}$ level, rumen ammonia, and plasma urea nitrogen. In this study, the reduction in rumen VFA, ammonia and plasma urea concentration partly reflects a negative energy and nitrogen balance in the rumen. Protozoa are responsible for extensive ammonia production in the rumen (Warner, 1956). In the present study, the number of protozoa decreased during dry-off. It is thus possible that the reduction in protozoa number contributed to the drop in rumen ammonia concentration. A reduction of the protozoa number of the same magnitude has been observed in fasting steers (Galyean et al., 1981) and in buffaloes fed wheat straw (Rajvir et al., 1996). When the starved animals in those studies were refed, the number of protozoa rapidly returned to the number before starvation. In the present study, however, the number of protozoa remained low $12 \mathrm{~d}$ after the introduction of the dry-period feed ration. It thus appears that both dry-off procedures induced a long-lasting disturbance of the rumen environment.

There were significant treatment $\times$ day interactions for ruminal fluid $\mathrm{pH}$ and VFA concentration, most likely reflecting a more pronounced reduction of VFA production during dry-off in cows fed straw. This was expected because these cows had a lower DM intake combined with a lower digestibility of the diet during dry-off. Furthermore, there was a significant interaction between treatment and day regarding the molar proportions of the individual VFA. Thus cows representing the straw treatment showed an increased proportion of Ac reflected by a reduction of both $\mathrm{Pr}$ and $\mathrm{Bu}$. A similar response was observed in lactating cows when silage was replaced with hydrogen peroxide-treated wheat straw reflecting an elevated fiber digestion (Cameron et al., 1990). In the present study, we used an esophageal tube to collect rumen fluid. Using such a technique involves a risk that the samples might be contaminated by saliva. However, the obtained ruminal $\mathrm{pH}$ values must be regarded as reasonable with regards to the actual diets.

\section{CONCLUSIONS}

The 2 dry-off treatments appeared to be similarly efficient in reducing milk production. The straw treatment, however, resulted in a more pronounced increase in plasma NEFA and lower plasma insulin values during dry-off indicating a deep negative energy balance. Primiparous cows had higher NEFA and lower leptin concentration than multiparous cows, indicating a more unbalanced metabolism. The ruminal fluid of cows receiving the straw treatment showed a more marked reduction of the ruminal fluid VFA concentration mir- 
rored by a higher $\mathrm{pH}$ when compared with cows subjected to the silage treatment.

\section{ACKNOWLEDGMENTS}

Financial support from the Swedish Farmers Foundation for Agricultural Research (No. 0230021) and Animal Welfare for Quality in Food Production project at the Swedish University of Agricultural Sciences is gratefully acknowledged. The authors thank Anne Odelström for technical assistance and for performing the protozoa counting, and Carole Delavaud for plasma leptin measurement.

\section{REFERENCES}

Agenäs, S., K. Dahlborn, and K. Holtenius. 2003. Changes in metabolism and milk production during and after feed deprivation in primiparous cows selected for different milk fat content. Livest. Prod. Sci. 83:153-164.

Andersson, R., and B. Hedlund. 1983. HPLC analysis of organic acids in lactic acid fermented vegetables. Z. Lebensm. Unters. Forsch. 176:440-443.

Baumrucker, C. R. 1985. Amino acid transport systems in bovine mammary tissue. J. Dairy Sci. 68:2436-2451.

Bocquier, F., M. Bonnet, Y. Faulconnier, M. Guerre-Millo, P. Martin, and Y. Chilliard. 1998. Effects of photoperiod and feeding level on adipose tissue metabolic activity and leptin synthesis in the ovariectomized ewe. Reprod. Nutr. Dev. 38:489-498.

Bonnet, M., C. Delavaud, J. Rouel, and Y. Chilliard. 2005. Pregnancy increases plasma leptin in nulliparous but not primiparous goats while lactation depresses it. Domest. Anim. Endocrinol. 28:216-233.

Broderick, G. A., and J. H. Kang. 1980. Automated simultaneous determination of ammonia and total amino acids in ruminal fluid and in vitro media. J. Dairy Sci. 63:64-75.

Cameron, M. G., G. C. Fahey, Jr., J. H. Clark, N. R. Merchen, and L. L. Berger. 1990. Effects of feeding alkaline hydrogen peroxidetreated wheat straw-based diets on digestion and production by dairy cows. J. Dairy Sci. 73:3544-3554.

Capuco, A. V., R. M. Akers, and J. J. Smith. 1997. Mammary growth in Holstein cows during the dry period: Quantification of nucleic acids and histology. J. Dairy Sci. 80:477-487.

Chelikani, P. K., J. D. Ambrose, D. H. Keisler, and J. J. Kennelly. 2004. Effect of short-term fasting on plasma concentrations of leptin and other hormones and metabolites in dairy cattle. Domest. Anim. Endocrinol. 26:33-48.

Chilliard, Y., M. Bonnet, C. Delavaud, Y. Faulconnier, C. Lerou, J. Djiane, and F. Bocquier. 2001. Review: Leptin in ruminants. Gene expression in adipose tissue and mammary gland, and regulation of plasma concentration. Domest. Anim. Endocrinol. 21:271-295.

Chilliard, Y., M. Doreau, F. Bocquier, and G. E. Lobley. 1995. Digestive and metabolic adaptations of ruminants to variations in food supply. 4. Int. Symp. Nutr. Herbivores. Clermont-Ferrand (FRA). Pages 329-360 in Recent Developments in the Nutrition of Herbivores. M. Journet, E. Grenet, M. H. Farce, M. Thériez, and C. Demarquilly, ed. INRA Publ., Paris, France.

Davis, S. R., and R. J. Collier. 1985. Mammary blood flow and regulation of substrate supply for milk synthesis. J. Dairy Sci. 68:1041-1058.

Delavaud, C., A. Ferlay, Y. Faulconnier, F. Bocquier, G. Kann, and Y. Chilliard. 2002. Plasma leptin concentration in adult cattle: Effects of breed, adiposity, feeding level, and meal intake. J. Anim. Sci. 80:1317-1328.

Dingwell, R., D. Kelton, K. Leslie, and V. Edge. 2001. Deciding to dry-off: Does level of production matter? Pages 69-79 in Proc. Natl. Mastitis Council. Ann. Meeting. Ontario, Canada. Natl. Mastitis Council, Inc., Arlington, VA.
Dingwell, R. T., K. E. Leslie, Y. H. Schukken, J. M. Sargeant, L. L. Timms, T. F. Duffield, G. P. Keefe, D. F. Kelton, K. D. Lissemore, and J. Conklin. 2003. Association of cow and quarter-level factors at drying-off with new intramammary infections during the dry period. Prev. Vet. Med. 63:75-89.

Drackley, J. K. 1999. Biology of dairy cows during the transition period: The final frontier. J. Dairy Sci. 82:2259-2273.

Duffield, T. 2000. Subclinical ketosis in lactating dairy cattle. Vet. Clin. North Am. Food Anim. Pract. 16:231-253.

Farr, V. C., C. G. Prosser, and S. R. Davis. 2000. Effects of mammary engorgement and feed withdrawal on microvascular function in lactating goat mammary glands. Am. J. Physiol. Heart Circ. Physiol. 279:813-818.

Galyean, M. L., R. W. Lee, and M. E. Hubert. 1981. Influence of fasting and transit on ruminal and blood metabolites in beef steers. J. Anim. Sci. 53:7-18.

Goering, H. K., and P. J. Van Soest. 1970. Forage Fiber Analyses (Apparatus, Reagents, Procedures, and Some Applications). Agric. Handbook No. 379. ARS-USDA, Washington, DC.

Hamann, J., and F. Dodd. 1992. Milking routines. Pages 69-96 in Machine Milking and Lactation. A. J. Bramley, F. H. Dodd, G. A. Mein, and J. A. Bramley, ed. Insight Books, Berkshire, UK.

Holtenius, K., S. Agenäs, C. Delavaud, and Y. Chilliard. 2003. Effects of feeding intensity during the dry period. 2. Metabolic and hormonal responses. J. Dairy Sci. 86:883-891.

Kristensen, N. B., G. Gabel, S. G. Pierzynowski, and A. Danfaer. 2000. Portal recovery of short chain fatty acids infused into the temporarily isolated and washed reticulo-rumen of sheep. Br. J. Nutr. 84:477-482.

Lindgren, E. 1979. Vallfodrets näringsvärde bestämt in vitro och med olika laboratoriemetoder (in Swedish with English summary). Dep. Anim. Nutr. Mgmt. Swedish Univ. Agric. Sci. Rapport 45. SLU, Sweden.

Marini, J. C., and M. E. Van Amburgh. 2003. Nitrogen metabolism and recycling in Holstein heifers. J. Anim. Sci. 83:545-552.

Meikle, A., M. Kulcsar, Y. Chilliard, H. Febel, D. Cavestany, and P. Chilibroste. 2004. Effects of parity and body condition at parturition on endocrine and reproductive parameters of the cow. Reproduction 127:727-737.

Murphy, M., M. Akerlind, and K. Holtenius. 2000. Rumen fermentation in lactating cows selected for milk fat content fed two forage to concentrate ratios with hay or silage. J. Dairy Sci. 83:756-764.

Nielsen, M. O., and K. Jacobsen. 1993. Changes in mammary glucose and protein uptake in relation to milk synthesis during lactation in high- and low-yielding goats. Comp. Biochem. Physiol. 106A:359-365.

Nielsen, M. O., T. G. Madsen, and A. M. Hedeboe. 2001. Regulation of mammary glucose uptake in goats: Role of mammary gland supply, insulin, IGF-1 and synthetic capacity. J. Dairy Res. 68:337-349.

Page, T., and N. J. Kuhn. 1986. Arteriovenous glucose differences across the mammary gland of the fed, starved, and re-fed lactating rat. Biochem. J. 239:269-274.

Pryce, J., R. R. Veerkamp, R. Thompson, W. Hill, and G. Simm. 1998. Genetic parameters of common health disorders and measures of fertility in Holstein Friesian dairy cattle. Anim. Sci. 65:353-360.

Rajvir, S., I. Salim, D. V. Singh, M. S. Setia, R. Singh, and S. Iqbal. 1996. Effect of exclusive feeding of wheat straw on rumen microbes and metabolites in buffalo calves (Bubalus bubalis). Buffalo J. 12:1-9.

Rennison, M. E., M. Kerr, C. V. P. Addey, S. E. Handel, M. D. Turner, C. J. Wilde, and R. D. Burgoyne. 1993. Inhibition of constitutive protein secretion from lactating mouse mammary cells by FIL (feedback inhibitor of lactation), a secreted milk protein. J. Cell Sci. 106:641-648.

SAS Institute. 2001. SAS/Stat Software. Release 8.2. SAS Inst., Inc., Cary, NC.

Shennan, D. B., and M. Peaker. 2000. Transport of milk constituents by the mammary gland. Physiol. Rev. 80:925-951.

Skidmore, A., K. Peeters, C. Sniffen, and A. Brand. 1997. Monitoring dry period management. Page 173 in Herd Health and Production 
Management in Dairy Practice. A. Brant, J. Noordhuizen, and Y. Schukken, ed. Wageningen Pers., Wageningen, The Netherlands. Spörndly, R. 2003. Fodertabell för idisslare. Rapport 257, Dept. of Anim. Nutr. and Management, Swedish Univ. of Agri. Sci., Uppsala, Sweden (in Swedish).

Stefano, B., M. Colitti, G. Gabai, C. H. Knight, and C. J. Wilde. 2002. Mammary apoptosis and lactation persistency in dairy animals. J. Dairy Res. 69:37-52.

Stelwagen, K., and S. J. Lacy-Hulbert. 1996. Effect of milking frequency on milk somatic cell count characteristics and mammary secretory cell damage in cows. Am. J. Vet. Res. 57:902-905.
Threadgold, L. C., and N. J. Kuhn. 1984. Monosaccharide transport in the mammary gland of the intact lactating rat. Biochem. J. 15:213-219.

Vernon, R. G., and C. M. Pond. 1997. Adaptations of maternal adipose tissue to lactation. Mammary Gland Biol. Neoplasia 2:231-241.

Warner, A. C. 1956. Proteolysis by microorganism. J. Gen. Microb. 14:749-762.

Wilde, C. J., C. V. Addey, J. M. Bryson, L. M. Finch, C. H. Knight, and M. Peaker. 1998. Autocrine regulation of milk secretion. Biochem. Soc. Symp. 63:81-90. 